\title{
Charcot-Marie-Tooth disease type 1E
}

INSERM

\section{Source}

INSERM. (1999). Orphanet: an online rare disease and orphan drug data base. CharcotMarie-Tooth disease type 1E. ORPHA:90658

Charcot-Marie-T ooth disease type 1E (CMT1E) represents a rare subtype of CMT1 (see this term) characterized by a variable clinical presentation. Onset within the first two years of life with a delay in walking is not uncommon; however, onset may occur later. CMT1E is caused by point mutations in the PMP22 (17p12) gene. The disease severity depends on the particular PMP22 mutation, with some cases being very mild and even resembling hereditary neuropathy with liability to pressure palsies, while others having an earlier onset with a more severe phenotype (reminiscent of Dejerine-Sottas syndrome; see these terms) than that seen in CMT1A, caused by gene duplication. These severe cases may also report deafness and much slower motor nerve conduction velocities compared to CMT 1A patients. 